\title{
PRIMARY BALANCE, PUBLIC DEBT AND FISCAL VARIABLES IN POSTSOCIALIST MEMBERS OF THE EUROPEAN UNION
}

\author{
Vratislav Izák*
}

\begin{abstract}
:
The primary balance has influenced the unit costs of debt servicing in 10 postsocialist members of the EU. The effects of the GDP growth and the inflation are equally robust and significant. The coefficients of lagged debt are at variance with the expectations from Bohn's 1998 paper, and one cannot speak until now about the corrective actions of fiscal authorities in these countries. Only Poland has had on average a higher real long-term interest rate than the growth rate. Other countries could stabilize their debt-GDP ratio by running a primary deficit. But comparing the level of investment with profits only in Slovenia one can speak about the dynamic inefficiency. Especially in the Czech Republic and Slovakia the relationship between debt and deficit is blurred by high negative stock-flow adjustments.
\end{abstract}

Keywords: primary balance, public debt, panel analysis, postsocialist members of EU

JEL Classification: E 62, H 63

\section{Introduction}

a) The fiscal variables, including the primary fiscal balance, have had the influence on borrowing costs in industrial countries (Caselli, Giovannini, Lane, 1998 and also Ardagna, Caselli, Lane, 2004). In particular, an improvement in the primary balance is associated with a significant reduction in debt servicing costs, amplifying the effects of primary adjustment on the state of public finances. The cost of debt servicing depends on the variables that determine the debt dynamics: primary balance, outstanding debt, inflation and growth. A key result concerns the relationship between the primary balance and the cost of debt servicing in 10 postsocialist countries which are nowadays the new members of the EU. Also in these countries a substantial portion of the variation in the borrowing costs can be attributed to "fundamentals".

b) One approach to assessing debt sustainability is to look at the relationship between fiscal policy instruments and the objectives of fiscal policy. Such reaction functions have a well-established tradition in the analysis of monetary policy and begin to be

* Faculty of Finance and Accounting, University of Economics, Prague (izak@vse.cz).

This work is supported by the Grant Agency of the Czech Republic, Project No. 402/09/0283. The paper was presented at the 64th IIPF congress on Demography and Pensions, Maastricht, August 2008. I am grateful to Y. Adema (Tilburg University) and M. Carlberg (H. Schmidt University, Hamburg) for fruitful comments. 
applied in the field of fiscal policy also (Bohn, 1998 and World Economic Outlook, September 2003). The primary fiscal balance is being considered the key operating target of the government and assumed to respond to public debt and also being affected by temporary factors (the business cycle, wars, inflation). The link between the adjusted primary balance and public debt was analysed and found convincing. The connection between the current policy actions and the long-run solvency lies in an assumption that the primary balance systematically responds to the past changes in the public debt which is in postsocialist countries far from being evident (Table 4).

c) The debt-stabilizing primary balance depends on the diference between the interest rate and growth rate of GDP (both real or nominal). For several decades we know that an economy that invests more than its total profit in steady state is dynamically inefficient (Phelps, 1961, Diamond, 1965). Our goal in established tradition (Public Debt, Bank of Italy, 2004, Fiscal Sustainability, Bank of Italy, 2000) is to make inferences about dynamic efficiency by comparing the real interest rate and the real growth rate in 10 new EU members and also by comparing the level of investment with the cash flows generated by production after the payment of wages in an uncertain world (Abel, Mankiw, Summers, Zeckhauser, 1989). In dynamically inefficient economies Ponzi schemes and gambles (Ball, Elmendorf, Mankiw, 1998) can succeed with certainty and public debt raises welfare because the economy has accumulated too much capital and crowding out is desirable. Of course, the great source of uncertainty is the impact of population ageing on the changes in government spending where some states in our sample belong to the most threatened (the Czech Republic, Hungary, Slovenia).

d) It is a well known fact that the change in the debt level can be larger or smaller than the government deficit. This diference between the change in the outstanding debt stock and the yearly deficit flow is known as the stock-flow adjustment (European Economy-Public Finances in EMU, 2005). The analysis of SFA has become more important as the EU budgetary surveillance may have provided incentives for shifting items from the deficit to the SFA. A high negative SFA shows the tendency to improve temporarily the debt development in some years in some countries of our sample (mainly Slovakia and the Czech Republic, Table 8).

The remainder of the paper is organized in four sections. Section 2 analyses the impact of fiscal variables on primary balance; Section 3 examines the possible responses of the primary balance to changes in the debt-GDP ratio; Section 4 discusses the relation between fiscal sustainability and dynamic efficiency and Section 5 briefly lookes at stock flow adjustment.

\section{Primary Balance, Interest Payments and Public Debt Service}

Abstracting from monetary financing that is forbidden in the European Union the general government budget deficit is the sum of the primary deficit (the excess of purchases $G$ over net tax receipts $T$ ) and of debt service (the real rate of interest $r$ times the existing debt stock B). To finance the deficit the government must borrow and issue new debt $\Delta \mathrm{B}$ : 


$$
\Delta \mathrm{B}=\mathrm{G}-\mathrm{T}+\mathrm{rB}
$$

Dividing both sides of (1) by real GDP Y :

$$
\Delta \mathrm{B} / \mathrm{Y}=\mathrm{G} / \mathrm{Y}-\mathrm{T} / \mathrm{Y}+\mathrm{r}(\mathrm{B} / \mathrm{Y})
$$

Box 1:

\section{A bit of algebra}

$\Delta(B / Y)=(Y \Delta B-B \Delta Y) / Y^{2}=(Y \Delta B) / Y^{2}-(B \Delta Y) / Y^{2}=(\Delta B / Y)-(\Delta Y / Y)(B / Y)$

Therefore $\Delta B / Y=\Delta(B / Y)+(\Delta Y / Y)(B / Y)$.

Taking into account that $\Delta \mathrm{Y} / \mathrm{Y}=\mathrm{g}$ and inserting for $\Delta \mathrm{B} / \mathrm{Y}$ into (2) we obtain:

$$
\Delta(\mathrm{B} / \mathrm{Y})+\mathrm{g}(\mathrm{B} / \mathrm{Y})=(\mathrm{G}-\mathrm{T}) / \mathrm{Y}+\mathrm{r}(\mathrm{B} / \mathrm{Y})
$$

and rearranging:

$$
\Delta(\mathrm{B} / \mathrm{Y})=(\mathrm{G}-\mathrm{T}) / \mathrm{Y}+\mathrm{r}(\mathrm{B} / \mathrm{Y})-\mathrm{g}(\mathrm{B} / \mathrm{Y})
$$

The change in the debt-GDP ratio (left side) equals to the primary budget deficit-GDP ratio (the first item on the right side) and the debt service-GDP ratio (the second item) adjusted for GDP growth rate (the third item).

Isolating the debt service on the left side:

$$
\mathrm{r}(\mathrm{B} / \mathrm{Y})=\Delta(\mathrm{B} / \mathrm{Y})+(\mathrm{T}-\mathrm{G}) / \mathrm{Y}+\mathrm{g}(\mathrm{B} / \mathrm{Y})
$$

From (5) is evident that to stabilize the debt-GDP ratio $^{1}, \Delta(\mathrm{B} / \mathrm{Y})=0$, the primary balance and the growth rate times the debt-GDP ratio must be able to finance the debt service.

Last but not least we can express the debt service in nominal terms:

$$
\mathrm{i}(\mathrm{B} / \mathrm{Y})=(\mathrm{T}-\mathrm{G}) / \mathrm{Y}+\mathrm{g}(\mathrm{B} / \mathrm{Y})+\pi(\mathrm{B} / \mathrm{Y})+\Delta(\mathrm{B} / \mathrm{Y})
$$

where $\mathrm{i}$... nominal interest rate

$\pi \ldots$ the inflation rate.

The factors influencing the debt service in nominal terms are:

a) the primary balance

b) the real growth rate

c) the inflation rate

d) the change in debt.

1 Blanchard (1990) sets $\Delta(B / Y)=0$ and solves for the debt-stabilizing tax rate $t^{*}$. When the actual tax rate $t$ is below the tax rate necessary to stabilize debt, the debt ratio will rise and vice versa. The gap between $t^{*}$ and $t$ is thus a measure of debt sustainability. What seems like a tax gap is in fact a primary deficit gap; ether spending or taxes can be equally adjusted to make the gap zero. The so called "good quality" fiscal adjustments have been marked by a strong emphasis on expenditure cuts rather than increased revenues (Budgetary Consolidation in EMU, 2001). 
Cross-section identifiers used in this paper in panel analysis are:
BG...Bulgaria
LV....Latvia
CZ....the Czech Republic
PL....Poland
EE....Estonia
RO...Romania
HU...Hungary
SL....Slovenia
LT....Lithuania
SK...Slovakia

Descriptive statistics in Table 1 gives the basic characteristics of the debt-GDP and primary deficit-GDP ratios in 10 postsocialist countries in 1995-2009 (15 observations; in some countries the series begins later than in 1995):

Table 1

Ratios Debt-GDP and Primary Deficit-GDP in 10 Postsocialist Countries (in \%)

\begin{tabular}{|c|c|c|c|c|c|c|c|c|c|c|}
\hline & BG & $\mathrm{CZ}$ & $\mathbf{E E}$ & HU & LT & LV & PL & RO & SL & SK \\
\hline \multicolumn{11}{|l|}{ debt } \\
\hline mean & 49.3 & 23.7 & 5.0 & 61.4 & 18.6 & 11.7 & 43.2 & 18.5 & 25.5 & 36.7 \\
\hline $\max$ & 105.1 & 30.5 & 8.8 & 71.7 & 23.7 & 14.5 & 47.6 & 25.0 & 28.5 & 50.2 \\
\hline $\min$ & 12.9 & 12.5 & 2.0 & 52.1 & 11.9 & 6.4 & 35.8 & 12.4 & 21.0 & 22.0 \\
\hline st.dev. & 29.5 & 7.6 & 1.8 & 5.4 & 3.5 & 2.5 & 4.4 & 5.0 & 2.6 & 8.3 \\
\hline obser. & 13 & 15 & 15 & 14 & 15 & 14 & 14 & 12 & 14 & 15 \\
\hline \multicolumn{11}{|l|}{ deficit } \\
\hline mean & -1.2 & 4.7 & -0.7 & 6.1 & 2.5 & 0.9 & 4.0 & 2.8 & 2.1 & 5.1 \\
\hline $\max$ & 3.4 & 13.4 & 3.6 & 9.2 & 11.9 & 3.9 & 6.3 & 4.6 & 4.2 & 12.2 \\
\hline $\min$ & -5.3 & 2.7 & -3.6 & 2.9 & 0.6 & -1.4 & 1.0 & 1.4 & 0.7 & 1.8 \\
\hline st.dev. & 2.3 & 2.8 & 1.9 & 2.0 & 2.8 & 1.5 & 1.5 & 1.2 & 1.1 & 3.2 \\
\hline obser. & 15 & 15 & 14 & 14 & 15 & 15 & 15 & 12 & 14 & 15 \\
\hline
\end{tabular}

The mean value of debt is very low in the Baltic states (unbelievable 5\% in Estonia) and also in some other countries. Comparable to the average of EU-15 (old countries of the EU) is only Hungary (61.4\%) with Bulgaria and Poland over $40 \%$.

Time-period specific descriptive statistics reveals that the debt-GDP ratio in the whole group peaked at 33\% in 1999 and hovered between 25.5 and $33 \%$ for most of the examined time period.

As concerns the primary balance the mean value is with sign plus, hence the deficit in 8 countries, and only Bulgaria and Estonia shows a surplus. High primary deficits are presented in Hungary (6\%), Slovakia, the Czech Republic and Poland (over $4 \%$ ). On the other hand the value for the EU-15 in this time period was a surplus mainly between 1 and $2 \%$.

Time-period specific descriptive statistics displays unambiguously the declining trend with the peak in the first year of our sample (a deficit of $4.6 \%$ in 1996) till to $1.3 \%$ in 2008 .

Figure 1 signifies a very close association between mean values of both debt and primary deficit in the period 1998-2008 for the selected country sample. 


\section{Figure 1}

Mean Values of Debt and Primary Deficit

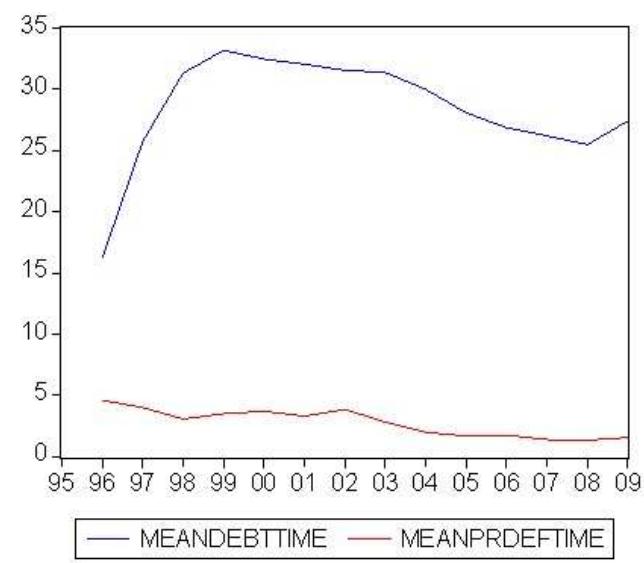

The remaining years are outliers at the beginning of the sample and are ignored.

The primary measure of a country's average interest cost of public debt is the ratio of general government interest expenditure to the stock of debt outstanding at the end of previous year.

The span for the mean value has been from 3.3\% in Estonia to 10.7\% in Romania. Time-period specific statistics again displays a declining trend since 1999 (the peak at $10.3 \%$ ) till 2006 (the bottom at $4.7 \%$ ) with a slight increase in following years.

The average interest cost of the debt may be hypothesized to depend on the variables affecting the debt dynamics (see above). Hence one can write (Caselli, Giovannini, Lane, 1998):

$$
\mathrm{i}_{\mathrm{it}}=\mathrm{a}_{0 \mathrm{i}}+\mathrm{a}_{1} \mathrm{pd}_{\mathrm{it}}+\mathrm{a}_{2} \pi_{\mathrm{it}}+\mathrm{a}_{3} \mathrm{~b}_{\mathrm{it}}+\mathrm{a}_{4} \mathrm{~g}_{\mathrm{it}}+\mathrm{u}_{\mathrm{it}}
$$

where the $a_{j}$ 's are coefficients; $i$ indexes countries $(i=1,2, \ldots .10)$ and $t$ time.

We have seen above that each country in our sample has had its own base level of the average implicit interest cost of public debt so that the equation should have a different intercept for each country (fixed effect). Specific intercepts can absorb any permanent differences across countries.

A government running a primary deficit faces higher interest costs, hence the coefficient $a_{1}$ should have a sign plus. As is well known the effect of inflation on the debt dynamics is ambiguous. On the one side, inflation worsens the debt dynamics by necessitating higher nominal interest rates and on the other side it improves the debt dynamics by raising the growth rate of nominal GDP. The coefficient for the debt-GDP ratio is predicted to be positive and the magnitude should be plausible. Last but not least the rate of growth of real GDP should lower the cost of debt. 
We apply a test to check whether fixed effects should be included in the model. The common constant method (also called the pooled OLS method) of estimation presents results under the principal assumption, that there are no differences among the data matrices of the cross-sectional dimension. It implies that there are no differences between the estimated cross sections. It is useful under the hypothesis that the data set is a priori homogenous which seems not to be our case.

The standard F-test is used to check fixed effects against the simple common constant OLS method. The null hypothesis is that all the constants are the same (homogenity), and that therefore the common constant method is applicable.

Table 2

Estimates for Alternative Specifications

\begin{tabular}{|l|r|r|r|}
\hline Explanatory variables & $\mathbf{( 1 )}$ & $\mathbf{( 2 )}$ & $\mathbf{( 3 )}$ \\
\hline \multirow{2}{*}{ Debt (b) } & 0.04 & -0.06 & -0.05 \\
& $(3.45)$ & $(-4.84)$ & $(-5.40)$ \\
\hline \multirow{2}{*}{ Primary deficit (pd) } & 0.52 & 0.27 & 0.20 \\
& $(7.69$ & $(3.34)$ & $(2.27)$ \\
\hline \multirow{2}{*}{ GDP growth (g) } & 0.22 & -0.32 & -0.35 \\
& $(4.23)$ & $(-4.88)$ & $(-4.89)$ \\
\hline \multirow{2}{*}{ Inflation rate $(\pi)$} & 0.34 & 0.23 & 0.27 \\
\hline $\mathrm{R}_{\text {adi }}$ & $(10.17)$ & $(8.13)$ & 0.73 \\
\hline Observations & 0.39 & 0.69 & 126 \\
\hline
\end{tabular}

(1)...common constant method.

(2)...fixed effects (cross-section weights), 1996-2009.

(3)...fixed effects (cross-section weights), 1997-2009.

T-statistic under the coefficients in brackets.

Comparing (1) with (2) the F-statistic is 15.69 and is bigger than the F critical (2.56 for $\mathrm{N}_{1}=9$ and $\mathrm{N}_{2}=120$ at 1 percent significant level). So we reject the null and accept that the fixed model captures here all effects which are specific to a particular country and which do not vary over time.

The results confirm the expectations (slightly better results for the period 1997-2009) as concerns the sign for GDP growth, primary deficit and inflation. The sign for debt is bad in spite of the fact that the coefficient is very small.

The results confirm the relevance of primary deficit to implicit costs. For all specifications, a government running a primary deficit faces significantly higher borrowing costs. The magnitude of the coefficients is large: a one-percentage point increase in the primary deficit is associated with an increase in the unit cost of debt servicing of over 20 basis points.

Equally robust and significant are the effects of the GDP growth. The effects are very strong, maybe due to the high growth rate in postsocialist countries. Increasing the growth rate by 1 percentage point reduces the unit cost of debt by more than 30 basis points. 
The effects of inflation on the cost of debt are also quite strong. On the average 1 percentage point of inflation worsens debt dynamics by more than 25 basis points.

The results for the debt-GDP ratio have a bad sign with the exception of the common constant method. The coefficients are very small, but statistically significant. The same problem with the coefficients for the debt has been encountered in the paper of Caselli, Giovannini and Lane, 1998. According to the authors one possible explanation can be division bias, since the dependent variable is interest expenditure divided by the stock of debt.

\section{Primary Balance, Reaction Function and Public Debt}

The primary balance is regarded as a target for policy intervention to secure fiscal sustainability. Government should on average run a sufficiently large primary surplus to ensure that it has a positive or zero net wealth.

From equation (5), if we write $\mathrm{b}=\mathrm{B} / \mathrm{Y}$ and $\mathrm{ps}=(\mathrm{T}-\mathrm{G}) / \mathrm{Y}$, we deduce the size of the primary surplus required to stabilize the debt-GDP ratio:

$$
\mathrm{ps}=(\mathrm{r}-\mathrm{g}) \mathrm{b}
$$

where ps is the primary surplus.

The relationship between $r$ and $g$ (both real or nominal) indicates whether or not government must run a primary surplus:

a) if $r>g$, then government will need to run a primary surplus to prevent an increase in the debt-GDP ratio;

b) if $\mathrm{r}<\mathrm{g}$, then government can run a primary deficit without putting upward pressure on the debt-GDP ratio.

The differential $(\mathrm{r}-\mathrm{g})$ together with the debt-GDP ratio determines the primary surplus government needs to run to prevent a change in the mentioned ratio. The focus is on the size of the primary surplus and the change in the ratio.

To establish sustainability, government should run a primary surplus sufficient to cover the excess caused by the real interest rate over the real growth rate (a sustainable primary surplus). E.g. for a debt-GDP ratio of $60 \%$, each 1 percentage point gap between $r$ and $g$ implies a required primary surplus of $0.6 \%$ of GDP. The higher the existing debt ratio, the larger the primary surplus required per 1 percentage point $(\mathrm{r}-\mathrm{g})$ gap.

According to the influential paper of Bohn (1998) one can find direct evidence for corrective actions by examining the response of the primary surplus to changes in the debt-GDP ratio. The primary balance response positively to increases in debt, hence it ensures that the intertemporal government budget constraint holds. Any large increase in debt due to "large negative shocks" is eventually reversed through primary surpluses. A positive response shows that the government is taking actions-reducing mainly mandatory expenditure or raising revenue-that counteracts the changes in debt. Hence a systematic relationship between the debt-GDP ratio and the primary surplus is to be searched. 
Figure 1 has shown an association between mean values of the debt-GDP ratio and mean values of the primary deficit in the sample of 10 postsocialist countries since 1998.

A more detailed picture is revealed by Figure 2 displaying an association in single countries. At the first glance what is, with some exceptions, striking into eyes the paralell movement of both variables which contradicts the governments responses.

Figure 2

Debt and Primary Deficit
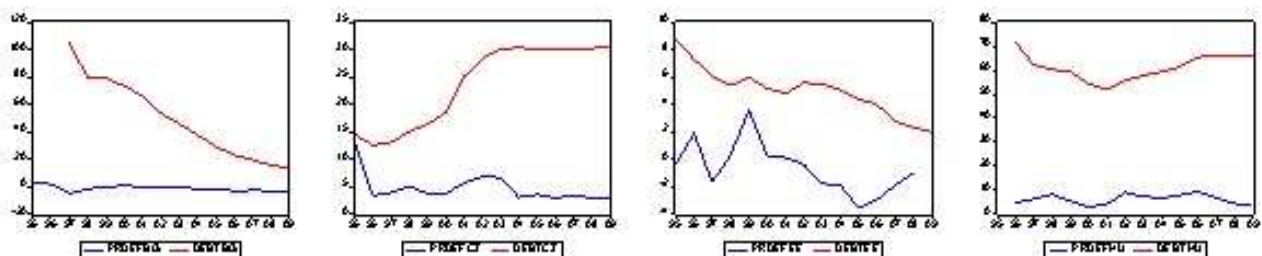

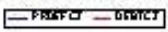
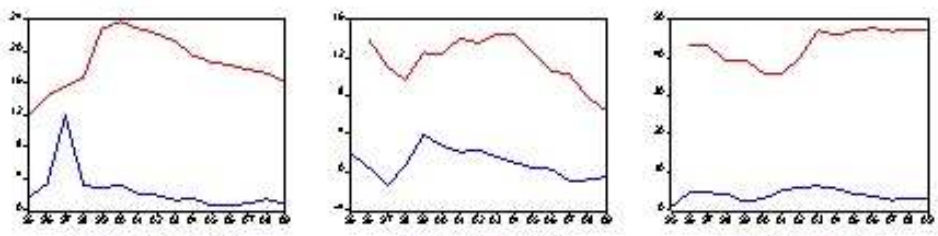

-

- मालm_-

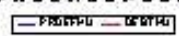
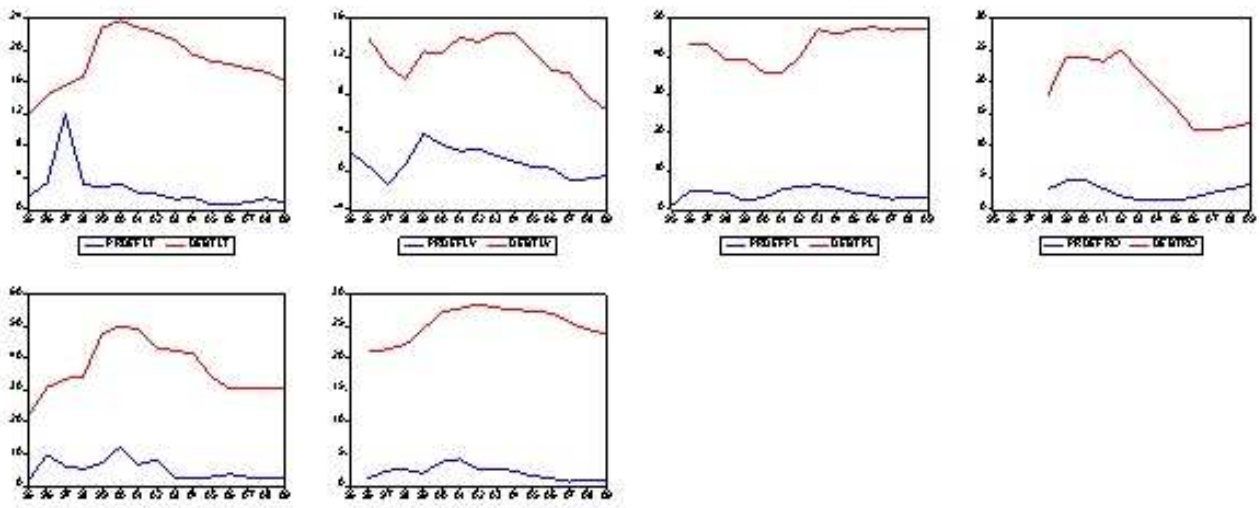

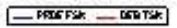

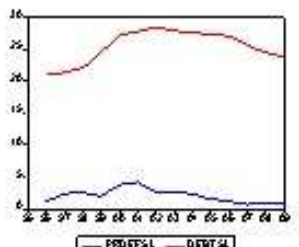

- करकात - सकाष

Table 3 shows the means of primary deficit (ratio to GDP), growth rate of the gross domestic product, ratios to GDP of both public debt and social expenditures (social transfers in kind plus social benefits other than social transfers in kind) in the time horizon 1996-2009 for our 10 countries. What is worth of mentioning is:

a) a clearly downward trend in primary deficit

b) growth rate of GDP hovering mainly around 5\% yearly

c) a downward trend of public debt (with the exception of the first three years)

d) the same as ad c) can be asserted for social expenditure as a dummy variable. 
Table 3

Means of Primary Deficit, GDP, Public Debt and Social Expenditure (1996-2009)

\begin{tabular}{|l|c|c|c|c|}
\hline & Primary deficit & GDP-growth rate & Public debt & Social expenditure \\
\hline 1996 & 4.57 & 5.10 & 14.33 & 0.75 \\
\hline 1997 & 3.99 & 6.18 & 26.86 & 0.75 \\
\hline 1998 & 3.04 & 4.14 & 34.57 & 0.56 \\
\hline 1999 & 3.49 & 1.80 & 30.00 & 0.80 \\
\hline 2000 & 3.69 & 4.43 & 33.20 & 0.80 \\
\hline 2001 & 3.30 & 4.62 & 32.48 & 0.70 \\
\hline 2002 & 3.83 & 4.65 & 32.07 & 0.70 \\
\hline 2003 & 2.81 & 5.36 & 31.57 & 0.60 \\
\hline 2004 & 1.98 & 6.38 & 31.40 & 0.40 \\
\hline 2005 & 1.67 & 6.32 & 30.02 & 0.50 \\
\hline 2006 & 1.74 & 7.50 & 28.10 & 0.40 \\
\hline 2007 & 1.37 & 6.81 & 26.88 & 0.20 \\
\hline 2008 & 1.32 & 5.78 & 26.20 & 0.20 \\
\hline 2009 & 1.53 & 5.36 & 28.07 & 0.22 \\
\hline
\end{tabular}

The Barro's tax-smoothing model implies the existence of nondebt determinants of the primary surplus which in our case are represented by the potential GDP gap and higher than average social expenditures. The dummy takes the value of 1 if higher than the average for a given country in the examined time period and 0 otherwise. In such a way we measure "abnormal" government expenditures. The estimation of fiscal policy reaction function has been focusing on two critical characteristics of discretionary fiscal policy - the response to cyclical fluctuations measured by the potential output gap and the sensitivity to movements in the public debt.

The estimated equation is:

$$
\mathrm{pd}_{\mathrm{it}}=\beta_{01}+\beta_{1} \mathrm{~b}_{\mathrm{it}-1}+\beta_{2} \mathrm{og}_{\mathrm{it}}+\beta_{3} \mathrm{ex}_{\mathrm{it}}+\mathrm{u}_{\mathrm{it}}
$$

Some estimates have been summarized in Table 4. Primary deficit is the dependent variable. The output gap enters, as expected negatively, in all our specifications and the coefficients are statistically significant. The gap of 1 percentage point lowers the primary deficit by approximately $20-30$ basis points. The coefficients of lagged debt are at variance with the expectations from Bohn's paper, because the primary deficit is an increasing function of the debt-GDP ratio. Therefore one cannot speak until now about the corrective actions of fiscal authorities in 10 postsocialist countries. The increase of lagged debt by 1 percentage point has led to an increase in primary deficit in the following year by 3-6 basis points. The impact of over average social expenditures (dummy 1, otherwise 0 ) as a rough proxy for extraordinary government spending has been highly significant. There are no great differences between the impact of output gap and the growth rate of real GDP. The impact of cycle seems to be weak (also according to the anecdotal evidence). 
Table 4

Estimates for Alternative Specifications

\begin{tabular}{|c|c|c|c|c|}
\hline Explanatory variable & (1) & $(2)$ & (3) & (4) \\
\hline debt (b-1) & $\begin{array}{c}0.0065^{* * *} \\
(9.74)\end{array}$ & $\begin{array}{c}0.0594 * * * \\
(2.99)\end{array}$ & $\begin{array}{c}0.0312 * * * \\
(2.46)\end{array}$ & $\begin{array}{c}0.0529 * \\
(1.74)\end{array}$ \\
\hline output gap (og) & $\begin{array}{l}-0.3182 * * * \\
(-4.42) \\
\end{array}$ & $\begin{array}{c}-0.2005^{* *} \\
(-2.28)\end{array}$ & $\begin{array}{c}-0.2772 * * * \\
(-5.63)\end{array}$ & $\begin{array}{c}-0.1767 * * * \\
(-2.45)\end{array}$ \\
\hline social expenditure (ex) & $\begin{array}{l}1.1767 * * * \\
(4.74)\end{array}$ & $\begin{array}{r}0.1169 \\
(0.47)\end{array}$ & $\begin{array}{c}1.3864 * * * \\
(7.22)\end{array}$ & $\begin{array}{c}0.5370 * * * \\
(2.56)\end{array}$ \\
\hline \multirow[t]{2}{*}{$\operatorname{AR}(1)$} & - & $0.8180 * * *$ & - & $0.4968 * * *$ \\
\hline & & $(13.82)$ & & $(6.28)$ \\
\hline $\mathrm{R}_{\text {adi }}^{2}$ & 0.6 & 0.82 & 0.81 & 0.87 \\
\hline DW & 0.74 & 1.82 & 1.51 & 1.87 \\
\hline Observations & 100 & 90 & 100 & 90 \\
\hline
\end{tabular}

T-statistics are given in brackets.

$* * *, * *,{ }^{*}$, denote, respectively, significance at 1,5 and $10 \%$ confidence.

(1)...common-constant method, cross-section weights.

(2)...common constant method, cross-section weights, AR differencing.

(3)...fixed effects, cross-section weights (White s.e.).

(4)...fixed effects, cross-section weights (White s.e.), AR differencing.

The following table displays cross-section specific coefficients for lagged debt, output gap (and rate of growth of real GDP) and our measure of "abnormal" social expenditures.

Table 5

Cross-section Specific Coefficients

\begin{tabular}{|l|c|c|c|c|}
\hline Spec.regressor & Social exp. & Debt-lag & GDP growth & Output gap \\
\hline Bulgaria & 0.7794 & $0.0275^{* * *}$ & -0.0071 & -0.0751 \\
\hline Czech Rep. & $1.3146^{* * *}$ & 0.0194 & $-0.6373^{* * *}$ & $-0.3574^{*}$ \\
\hline Estonia & $2.3074 * * *$ & 0.1414 & $-0.5121^{* * *}$ & $-0.6552^{* * *}$ \\
\hline Hungary & 1.2209 & $-0.2359^{*}$ & 0.4138 & 0.5824 \\
\hline Latvia & $1.5866^{* * *}$ & 0.2631 & $-0.3032^{* * *}$ & $-0.5990^{* * *}$ \\
\hline Lithuania & 0.1677 & 0.1352 & -0.0749 & -0.9118 \\
\hline Poland & 0.6262 & $0.1397^{*}$ & $-0.2909 *$ & $-0.9600^{* * *}$ \\
\hline Romania & 0.0500 & 0.0275 & $-0.2140^{* * *}$ & $-0.2112^{* * *}$ \\
\hline Slovenia & $1.3130^{* * *}$ & -0.0808 & -0.3647 & 0.1311 \\
\hline Slovakia & $4.2044 * * *$ & $0.1224 *$ & $-0.6337 * * *$ & -0.4574 \\
\hline Debt (-1) & $0.0270^{*}$ & - & $0.0449 * * *$ & $0.0372^{* * *}$ \\
\hline GDP & $-0.2947^{* * *}$ & $-0.3516^{* * *}$ & - & - \\
\hline Soc.exp. & - & $1.3481^{* * *}$ & $1.2695^{* * * *}$ & $1.2180^{* * *}$ \\
\hline $\mathrm{R}_{\text {adj }}^{2}$ & 0.83 & 0.82 & 0.82 & 0.83 \\
\hline DW & 1.83 & 1.85 & 1.90 & 1.75 \\
\hline Observations & 100 & 100 & 100 & 100 \\
\hline
\end{tabular}


Statistically significant (mainly at $1 \%$ confidence) for 6 countries is growth rate of real GDP and with a similar impact the additional calculation for the output gap (significant for the same 5 countries). "Abnormal" social expenditures are significant for 5 countries and debtlag for 4 countries (only in Hungary one has a sign corresponding to the corrective actions of government; remember that Hungary is a country with highest indebtedness in our sample).

\section{Fiscal Sustainability and Dynamic Efficiency}

The differential in equation (8) is one of the clues of fiscal sustainability. In a seminal paper of Blanchard (1990) the author assumes a positive $(\mathrm{r}-\mathrm{g})$. According to him this is an important assumption, one which was not satisfied expost in the 1970s, but has been amply satisfied since. When the growth rate asymptotically exceeds the interest rate the government does not have a sustainability constraint and can issue debt without ever needing to reimburse it.

Croce, Ramon (2003) rule out the case when $\mathrm{r}<\mathrm{g}$, because this would lead, in a steady state, to "inefficient capital overaccumulation". In this state of affairs the government can take advantage by running a Ponzi scheme, that is, it can issue debt at some date and roll it over forever. The specific condition that must be satisfied for the government to be able to run a Ponzi scheme in the Diamond model ${ }^{2}$ is that the equilibrium is dynamically inefficient, so that the real interest rate is less than the growth rate of the economy.

The majority of economists think that the posibility of a government Ponzi scheme is largely a theoretical curiosity, however. In the realistic case where the economy is not dynamically inefficient, Ponzi games are not feasible and the government must satisfy the traditional present value budget constraint.

From the point of view of public finance what is important is the implication that debt issuance is a possible solution to dynamic inefficiency. By getting individuals to hold some of their savings in the form of government debt rather than capital, the government can reduce the capital stock from its inefficiently high level (Romer, 2004).

In a previous paper of Phelps (1961) the author in his fable for growthmen defines a "golden age" and postulates that "along the optimal golden-age path, under conditions of natural growth, the rate of investment is equal to the competitive rate of profits" (p. 641).

The Diamond model shows that it is possible for a decentralized economy to accumulate capital betone the golden rule level and thus to produce an allocation that is Pareto inefficient. This raises the issue of whether actual economies might be dynamically inefficient. If they were, there would be important implications for public policy: the great concern about low rates of savings would be entirely misplaced and there would be an easy way of increasing both present and future consumption.

2 The Diamond's paper served to purposes: a) to examine long-run competitive equilibrium in a growth model; b) to explore the effects on this equilibrium of government debt. In his model the equilibrium interest rate equals the marginal product of capital in a competitive framework (1965, $\mathrm{p}$. 1130). The competitive solution may be dynamically inefficient (p. 1134). 
In the theoretical models a la Diamond, in a world of certainty, all interest rates are equal, hence there is no ambiguity in what is meant by the interest rate. The interest rate and the marginal product of capital are the same. But in a world of uncertainty the things are not so easy. Abel, Mankiw, Summers, Zeckhauser (1989) assert that: "Our goal is to ascertain which observable features of actual economies can be used to make inferences about dynamic efficiency and then to assess whether the United States economy is dynamically efficient". ${ }^{3}$

Table 6

Real Growth Rate of GDP and Real Long-term Interest Rate

\begin{tabular}{|c|c|c|c|c|c|c|c|c|c|}
\hline & 1998 & 1999 & 2000 & 2001 & 2002 & 2003 & 2004 & 2005 & 2006 \\
\hline \multicolumn{10}{|l|}{ BG } \\
\hline GDP & & & & & 4.5 & 5.0 & 6.6 & 6.2 & 6.1 \\
\hline IR & & & & & 3.7 & 4.6 & 0.2 & 0.1 & -3.6 \\
\hline \multicolumn{10}{|l|}{$\mathrm{CZ}$} \\
\hline GDP & & & 3.6 & 2.5 & 1.9 & 3.6 & 4.5 & 6.4 & 6.4 \\
\hline IR & & & 5.4 & 1.4 & 2.0 & 3.2 & 0.2 & 3.7 & 2.1 \\
\hline \multicolumn{10}{|l|}{ EE } \\
\hline GDP & 4.4 & 0.3 & 7.9 & 7.7 & 8.0 & 7.2 & 8.3 & 10.2 & 11.2 \\
\hline IR & 3.9 & 6.6 & 4.8 & 4.6 & 4.4 & 0.7 & 2.5 & -2.1 & -1.8 \\
\hline \multicolumn{10}{|l|}{ HU } \\
\hline GDP & & 4.2 & 5.2 & 4.1 & 4.4 & 4.2 & 4.8 & 4.1 & 3.9 \\
\hline IR & & 1.4 & -1.2 & -0.5 & -0.7 & 0.9 & 3.7 & 4.3 & 3.3 \\
\hline \multicolumn{10}{|l|}{ LT } \\
\hline GDP & & & & 6.6 & 6.9 & 10.3 & 7.3 & 7.9 & 7.7 \\
\hline IR & & & & 8.4 & 6.0 & 6.3 & 1.8 & -1.9 & -2.3 \\
\hline \multicolumn{10}{|l|}{ LV } \\
\hline GDP & & & & 8.0 & 6.5 & 7.2 & 8.7 & 10.6 & 11.9 \\
\hline IR & & & & 5.8 & 1.7 & 1.3 & -2.0 & -5.7 & -6.3 \\
\hline \multicolumn{10}{|l|}{ PL } \\
\hline GDP & & 4.5 & 4.3 & 1.2 & 1.4 & 3.9 & 5.3 & 3.6 & 6.1 \\
\hline IR & & 3.3 & 4.2 & 7.0 & 5.0 & 5.4 & 2.7 & 2.5 & 3.8 \\
\hline \multicolumn{10}{|l|}{ SK } \\
\hline GDP & & & 0.7 & 3.2 & 4.1 & 4.2 & 5.4 & 6.0 & 8.3 \\
\hline IR & & & -1.2 & 2.9 & 2.2 & 0.2 & -0.9 & 1.1 & 1.6 \\
\hline \multicolumn{10}{|l|}{ SL } \\
\hline GDP & & & & & & 2.8 & 4.4 & 4.1 & 5.7 \\
\hline IR & & & & & & 0.7 & 1.3 & 2.1 & 1.8 \\
\hline
\end{tabular}

3 And further: "In a competitive economy, therefore, the issue of dynamic efficiency can be resolved by comparing the level of investment with the cash flows generated by production after the payment of wages. More metaphorically, the key question is whether the capital sector is on net a spout or a sink, “p. 2. 
Following this line of thought Obstfeld, Rogoff (1996) claim that, because $r>g$ is equivalent to:

$$
\mathrm{rK} / \mathrm{Y}>\mathrm{g} \mathrm{K} / \mathrm{Y}
$$

a steady state is dynamically inefficient if and only if the share of profits in output is less than that of investment. A dynamically efficient economy does not invest more than $100 \%$ of its profits simply to maintain a constant ratio of capital to effective labour.

Table 7

\section{Investment and Profit}

\begin{tabular}{|c|c|c|c|c|c|c|c|c|c|c|c|c|}
\hline & 1995 & 1996 & 1997 & 1998 & 1999 & 2000 & 2001 & 2002 & 2003 & 2004 & 2005 & 2006 \\
\hline \multicolumn{13}{|l|}{ BG } \\
\hline GCF & 15.7 & 8.1 & 9.9 & 16.9 & 17.9 & 18.3 & 20.7 & 19.8 & 21.7 & 23.1 & 28.0 & 31.9 \\
\hline Profit & 29.7 & 38.5 & 44.1 & 34.9 & 36.5 & 46.4 & 45.0 & 44.4 & 43.0 & 44.0 & 44.0 & 45.4 \\
\hline \multicolumn{13}{|l|}{$\mathrm{CZ}$} \\
\hline GCF & 32.6 & 33.7 & 30.5 & 28.4 & 27.1 & 29.5 & 29.5 & 28.6 & 27.2 & 27.5 & 25.8 & 26.9 \\
\hline Profit & 44.9 & 43.3 & 43.2 & 45.4 & 44.9 & 44.5 & 44.2 & 42.3 & 40.8 & 41.8 & 42.1 & 42.5 \\
\hline \multicolumn{13}{|l|}{$\mathbf{E E}$} \\
\hline GCF & 27.5 & 27.8 & 31.4 & 31.3 & 25.7 & 28.7 & 28.1 & 32.4 & 33.2 & 35.0 & 34.1 & 38.2 \\
\hline Profit & 36.1 & 40.2 & 40.9 & 42.8 & 40.6 & 43.5 & 44.9 & 45.5 & 45.1 & 44.7 & 46.1 & 44.9 \\
\hline \multicolumn{13}{|l|}{$\mathrm{HU}$} \\
\hline GCF & 22.3 & 25.1 & 26.2 & 28.4 & 28.3 & 30.4 & 26.9 & 25.5 & 25.2 & 25.9 & 23.6 & 22.9 \\
\hline Profit & 33.8 & 35.9 & 38.2 & 39.3 & 41.6 & 40.6 & 39.3 & 39.5 & 38.5 & 37.6 & 37.4 & 40.3 \\
\hline \multicolumn{13}{|l|}{ LT } \\
\hline GCF & 23.5 & 21.6 & 25.5 & 25.5 & 22.5 & 19.8 & 20.6 & 22.1 & 23.2 & 24.0 & 25.1 & 27.0 \\
\hline Profit & 46.4 & 43.4 & 41.2 & 39.7 & 38.2 & 44.3 & 46.3 & 45.2 & 44.6 & 44.9 & 45.0 & 43.7 \\
\hline \multicolumn{13}{|l|}{$L V$} \\
\hline GCF & 14.4 & 17.5 & 19.6 & 24.2 & 23.4 & 23.7 & 26.6 & 26.7 & 26.8 & 33.2 & 34.4 & 37.9 \\
\hline Profit & 41.1 & 38.7 & 37.5 & 39.0 & 40.8 & 45.2 & 47.4 & 50.0 & 48.6 & 49.0 & 46.5 & 44.9 \\
\hline \multicolumn{13}{|l|}{ PL } \\
\hline GCF & 18.7 & 20.9 & 23.4 & 25.1 & 25.3 & 24.8 & 20.8 & 18.6 & 18.7 & 20.1 & 19.3 & 20.6 \\
\hline Profit & 34.8 & 32.9 & 33.0 & 34.2 & 34.7 & 36.9 & 35.2 & 37.5 & 39.8 & 44.0 & 44.7 & 46.7 \\
\hline \multicolumn{13}{|l|}{ RO } \\
\hline GCF & 24.3 & 25.9 & 20.6 & 17.7 & 16.1 & 19.5 & 22.6 & 21.7 & 21.8 & 23.8 & 22.7 & 24.2 \\
\hline Profit & 32.5 & 33.0 & 41.7 & 23.1 & 27.8 & 10.7 & 16.1 & 20.7 & 24.8 & 29.4 & 26.9 & 25.9 \\
\hline \multicolumn{13}{|l|}{ SK } \\
\hline GCF & 24.3 & 33.7 & 34.0 & 33.5 & 27.6 & 25.9 & 29.6 & 29.0 & 24.6 & 26.0 & 29.2 & 29.0 \\
\hline Profit & 49.9 & 50.6 & 49.8 & 47.7 & 49.5 & 49.8 & 51.1 & 50.5 & 50.6 & 51.8 & 52.1 & 53.1 \\
\hline \multicolumn{13}{|l|}{ SL } \\
\hline GCF & 22.9 & 22.7 & 23.9 & 25.1 & 27.5 & 27.5 & 25.0 & 24.1 & 25.5 & 27.7 & 27.3 & 28.4 \\
\hline Profit & 18.9 & 21.1 & 23.6 & 24.6 & 26.2 & 25.4 & 25.4 & 25.8 & 26.6 & 26.6 & 26.9 & 28.2 \\
\hline
\end{tabular}


Let us begin our analysis with the established tradition evaluating dynamic efficiency by comparing growth rates of real GDP and real long-term interest rates. In view of the limited number of the latter for 9 postsocialist countries the analysis is descriptive (for Romania we have real long-term interest rate for 2006 only; minus $2.9 \%$ ).

A glance at the Table 6 reveals that only one country has had on the average ${ }^{4}$ a higher real long-term interest rate than the growth rate. For Poland in the time period 1999-2006 the average growth rate was 3.79\%, whereas the average real long-term interest rate was slightly higher $(4.24 \%)$.

In other countries the interest rate was higher only in some years and often had a minus sign. Therefore applying the established tradition the conclusion would be the assertion of dynamic inefficiency.

Inserting the average values into equation (8) we can draw the partial conclusion that the other countries could stabilize their debt-GDP ratio by running a primary deficit! E.g. for the Czech Republic the debt ratio hovering around $30 \%$ in the last years could be stabilized by running the primary deficit of $0.47 \%$.

But we know that this conclusion would be wrong because we do not live in a neoclassical world of certainty. In a world of uncertainty we can gamble on the future development of crucial variables (Ball, Elmendorf, Mankiw, 1998). Estimating the effects of the gamble requires explicit modelling of the uncertainty concerning future economic growth and interest rates and first of all forecasting the impacts of population ageing on the total deficit.

Comparing the level of investment (gross capital formation) with profits we see in Table 7 that in our sample the capital sector is on net a spout and not a sink. The exception is Slovenia where in 9 years from 12 the profit rate has been lower than the level of investment. Hence in this case one can assert that the economy is dynamically inefficient.

\section{Stock-flow Adjustment}

In the theoretical analysis the debt as a stock item is the summation of flow items - the deficits. In reality the change in the debt level in any given year can be larger or smaller then the government deficit. This diference between the change in the outstanding debt stock and the yearly deficit flow is known as the stock-flow adjustment (SFA).

A positive SFA means that factors other than the government deficit increase the government debt. On the contrary, a negative SFA means that factors other than the government deficit redukce the government debt.

The analysis of SFA has become more important as the EU budgetary surveillance may have provided incentives for shifting items from the deficit to the SFA, that is, from above to below the line (European Economy-Public Finances in EMU, 2005).

The SFA exists because of differences in the basic accounting principles according to which the government deficit and debt are defined and compiled. Accordingly, the SFA can be split into three components along with these differences:

- differences between the accrual and cash base sof recording transactions;

- differences in the gross and net recording of transactions with financial assets;

- valuation effects and remaining statistical adjustments.

4 "It is better to use constant values of $r$ and $g$, say the averages over the last 10 years or so," Blanchard, 1990, p. 14. 
Consolidated general government financial statistics - summary pages (2007 edition) - metadata, have decomposed SFA as follows:

- net acquisition of financial assets;

- incurrence in liabilities not in the government debt;

- valuation effects and other changes in volume of government debt;

- statistical discrepancies.

The high level of the SFA in some postsocialist countries in both directions justifies a closer look at the relevant data:

Table 8

SFA in 8 Postsocialist Countries (in \% of GDP)

\begin{tabular}{|l|c|c|c|c|}
\hline & $\mathbf{2 0 0 2}$ & $\mathbf{2 0 0 3}$ & $\mathbf{2 0 0 4}$ & $\mathbf{2 0 0 5}$ \\
\hline CZ & -2.3 & -3.8 & 0.0 & -2.0 \\
\hline EE & 1.7 & 2.6 & 2.4 & 2.4 \\
\hline HU & 0.8 & 0.4 & 0.0 & -1.7 \\
\hline LT & -0.6 & -0.4 & -1.3 & 1.1 \\
\hline LV & -1.5 & 1.1 & 1.2 & 0.2 \\
\hline PL & 2.0 & 1.0 & -2.1 & 0.1 \\
\hline SK & -9.2 & -0.7 & 0.4 & -7.0 \\
\hline SL & 1.8 & -1.1 & 0.1 & -0.6 \\
\hline
\end{tabular}

Source: Compiled from Government Finance Statistics, summary tables, Eurostat, 2007 edition.

Whereas for Estonia we encounter large regular positive SFAs for all 4 years, on the contrary, the Czech Republic and especially Slovakia exhibit large negative values which blur the relationship between debt and deficit. High negative SFAs show the tendency to improve temporarily the debt development. More than half of the SFAs observed for 8 countries (data for Bulgaria and Romania are missing) exceed 1\% of GDP and for some countries even exceed $2 \%$ of GDP.

\section{Conclusions}

The results confirm the relevance of primary deficit to implicit costs. For all specifications, a government running a primary deficit faces significantly higher borrowing costs. The magnitude of the coefficients is large: a one percentage-point increase in the primary deficit is associated with an increase in the unit cost of debt servicing of over 20 basis points.

Equally robust and significant are the effects of the GDP growth. The very strong effects may be due to the high growth rate in postsocialist countries. Increasing the growth rate by 1 percentage point reduces the unit costs of debt by more than 30 basis points. The effects of inflation on the cost of debt are also quite strong. On the average 1 percentage point of inflation worsens debt dynamics by more than 25 basis points. The results for the debt-GDP ratio have had a bad sign with the exception of the common constant method. The coefficients are very small, but statistically significant. 
In the literature one can find direct evidence for corrective actions by examining the response of the primary surplus to change in the debt-GDP ratio. Hence also in the sample of 10 postsocialist countries a systematic relationship between the debt-GDP ratio and the primary surplus is searched.

The output gap of 1 percentage point lowers the primary deficit of approximately 20-30 basis points. The coefficients of lagged debt are at variance with the expectations from Bohn's paper, because the primary deficit is in our case an increasing function of the debt-GDP ratio. Therefore one cannot speak until now about the corrective actions of fiscal authorities in postsocialist countries. The increase of lagged debt by 1 percentage point has led to an increase in primary deficit in the following year by 5 basis points. The impact of over average social expenditures as a rough proxy for extraordinary government spending has been highly significant. There are no great differences between the impact of output gap and the growth rate of real GDP. Hence the impact of the business cycle seems to have been weak.

The differential $(\mathrm{r}-\mathrm{g})$ is very important for the fiscal sustainability. In a state of certainty when $r<g$ we encounter in a steady state inefficient capital overaccumulation. The government can issue debt and run it over forever.

In our sample only one country - Poland has had on the average a higher real long-term interest rate than the growth rate. For Poland in the time period 1999-2006 the average growth rate was $3.79 \%$, whereas the average interest rate was slightly higher $(4.24 \%)$. In the other countries the interest rate was higher only in some years and often had a minus sign. Inserting the average values we can draw the partial conclusion that the other countries could stabilize their debt-GDP ratio by running a primary deficit!

In a world of uncertainty we can gamble on the future. Estimating the effects of the gamble requires exploit modelling of future growth and interest rates and first of all forecasting the impacts of population ageing on the total deficit. Comparing the level of investment with profits only in Slovenia one can speak about the dynamic inefficiency.

The relationship between debt and deficits is incomplete disregarding the stock-flow adjustment. Whereas for Estonia we find large positive SFAs for all 4 years in 2002-2005, on the contrary, the Czech Republic and especially Slovakia exhibit large negative values which blur the relationship between debt and deficit. High negative SFAs reveal the tendency to improve temporarily the debt development. More than half of the SFAs observed for 8 countries exceed $1 \%$ of GDP and for some countries even in some years exceed $2 \%$ of GDP.

\section{Data}

Practically all data have been compiled from The Statistical Annex, autumn 2007, Eurostat.

The preliminary data for 2008 and 2009 stem from the national convergence programs submitted to the European Commission.

Table 10...GDP at 2000 Market Prices; annual percentage change; national currency Table 24...Price Deflator GDP at Market Prices

Table 32...Profit Share $=100$ - adjusted wage share; total economy

Table 62... Social Transfers in Kind

Table 63... Social Benefits other than Social Transfers in Kind 
Table 75...Net Lending (+) or Net Borrowing (-) excluding interest; general government

Table 76...General Government Consolidated Gross Debt

Main Economic Indicators 1961-2009

3.5...Gross Capital Formation

4.3...Potential GDP Gap

9.4...Real Long-term Interest Rate

Government Finance Statistics, Summary Tables 2/2007

Table B...Government Debt and Link with the Deficit

Line 58....Stock Flow Adjustment

\section{References}

Abel A., Mankiw G., Summers L., Zeckhauser R. (1989), "Assessing Dynamic Efficiency: Theory and Evidence." Review of Economic Studies. No. 1.

Ardagna S., Caselli F., Lane T. (2004), "Fiscal Discipline and the Cost of Public Debt Service: Some Estimates for OECD Countries." NBER WP 10788.

Balassone F., Franco D. (2000), "Assessing Fiscal Sustainability: A Review of Methods with a View to EMU." Fiscal Sustainability, Perugia, Bank of Italy.

Ball L., Elmendorf D., Mankiw G. (1998), "The Deficit Gamble“. Journal of Money, Credit and Banking. No. 4.

Blanchard O. (1990), Suggestions for a New Set of Fiscal Indicators. OECD, WP No.69.

Bohn H. (1998), "The Behavior of U.S. Public Debt and Deficits." The Quarterly Journal of Economics. No. 3.

Caselli F., Giovannini A., Lane T. (1998), "Fiscal Discipline and the Cost of Public Debt Service: Some Estimates for OECD Countries." IMF WP 98/55.

Croce E., Juan Ramon H. (2003), "Assessing Fiscal Sustainability: A Cross- Country Comparison." IMF WP 03/145.

Diamond P. (1965), "National Debt in a Neoclassical Growth Model." American Economic Review. No. 1 , Part 1.

EC (2008), “European Economy-Public Finances in EMU, 2000-2007." Brussels, European Commission.

EUROSTAT (2007), "Government Finance Statistics.” Eurostat, Summary Tables 2/2007.

Kogler-Toglhofer W., Zogler M. (2004), "The Impact of Different Fiscal Policy Regimes on Public Debt Dynamics. Public Debt." Perugia, Bank of Italy.

Lebow D. (2004), "Recent Fiscal Policy in Selected Industrial Countries." BIS, Basel. WP No. 162.

Martner R., Tromben V. (2004), "Public Debt Indicators in Latin American Countries: Snowball Effect, Currency Mismatch and the Original Sin." Public Debt, Perugia, Bank of Italy.

Obstfeld M., Rogoff K. (1996), Foundations of International Macroeconomics. Cambridge, Massachusetts.

Phelps E. (1961), "The Golden Rule of Accumulation: A Fable for Growthmen." American Economic Review. No. 4.

Romer D. (2004), Advanced Macroeconomics. New York, Mc Graw-Hill.

Eurostat (2007), Statistical Annex. Eurostat, Autumn 2007.

EC (2006), The Long-term Sustainability of Public Finances in the European Union. Brussels: European Commission.

IMF (2003), World Economic Outlook. IMF Washington, September 2003.

IMF (2004), World Economic Outlook. IMF Washington, September 2004. 